\title{
Mathematics Day: Elements and Applications of Mathematics in the Final Year Project
}

\author{
Noraishikin Zulkarnain ${ }^{1,2, *}$, Noorhelyna Razali ${ }^{2,3}$, Nuryazmin Ahmat Zainuri ${ }^{2,3}$, Haliza Othman ${ }^{2}$, \\ Alias Jedi ${ }^{2,3}$ \\ ${ }^{1}$ Department of Electrical, Electronic and Systems Engineering, Faculty of Engineering and Built Environment, Universiti Kebangsaan \\ Malaysia, UKM, Bangi, Selangor 43600, Malaysia \\ ${ }^{2}$ Department of Engineering Education, Faculty of Engineering and Built Environment, Universiti Kebangsaan Malaysia, UKM, Bangi, \\ Selangor 43600, Malaysia \\ ${ }^{3}$ Department of Mechanical and Manufacturing Engineering, Faculty of Engineering and Built Environment, Universiti Kebangsaan \\ Malaysia, UKM, Bangi, Selangor 43600, Malaysia
}

Received February 20, 2020; Revised July 2, 2020; Accepted July 20, 2020

Copyright $\bigcirc 2020$ by authors, all rights reserved. Authors agree that this article remains permanently open access under the terms of the Creative Commons Attribution License 4.0 International License

\begin{abstract}
Mathematics is one of the major subjects that every engineering student needs to learn. However, every student may have different views and interests on Mathematics subjects because of their different levels of thinking. To foster the appreciation of engineering students on the applications of Mathematics in engineering courses and help them apply and enhance their mathematical knowledge, the Fundamental Engineering Unit at the Faculty of Engineering and Built Environments, Universiti Kebangsaan Malaysia (UKM), organised the first 'Mathematics Day' on Thursday, May 4, 2017. For their final year project, 12 students participated in a competition where they used mathematical or statistical applications to create a poster. The competition was judged by the academic assessors, industry and UKM alumni. This study examines the mathematical elements and applications in students' posters. The relevance of the elements and topics in the Engineering Mathematics course in the posters is reviewed. Reports from students who were present during the competition are also analysed to determine the effectiveness of the activity. The expected outcome of the student reports is interpreted using a statistical descriptive method, and results indicate that the students had a positive reaction to the activity.
\end{abstract}

Keywords Mathematics Day, Engineering Mathematics, Final Year Project, Elements, Application

\section{Introduction}

Mathematics is an important element in engineering education, but students generally have problems in understanding mathematical concepts. Hence, effective teaching methods need to be practiced during the teaching and learning process. Instructional methods are the approaches used to deliver information in the teaching and learning process. Teachers use various teaching methods to deliver information or teaching objectives. Different approaches are also used for each subject taught by a lecturer. For example, the appropriate teaching method used by lecturers for subjects involving experiments is demonstration or explanation [1]. Efstathios, Maria and Chrystalla found several reasons of why many students are weak in their Mathematics and Science studies [2]. Amongst these reasons are poor education system and low interest, but the main reason is that the teaching method cannot attract students to explore the knowledge.

Therefore, the teaching method for Mathematics is very important in enhancing students' understanding of a course and ensuring they are able to master and improve their achievements in the course. [3-5]. Idris explained that various approaches can be used in the process of delivering mathematical ideas and skills. He also stated that in Mathematics teaching, various methods are often used so students can understand and master a skill [6-9]. Therefore, to foster the appreciation of engineering students on mathematics and engineering courses and enhance their mathematical knowledge in engineering courses, the Fundamental Engineering Unit (UPAK) at the Faculty of Engineering and Built Environments (FKAB), Universiti Kebangsaan Malaysia (UKM), organised the first 'Mathematics Day' program. Through the program, UPAK aspires to enhance students' appreciation of Mathematics and Statistics in engineering applications [10-14]. 


\section{Mathematics Day}

Mathematics Day aims to help students master mathematical and engineering courses more accurately, sustainably and effectively so that they can advance themselves in engineering courses. Additionally, it helps students open their minds to increase their appreciation and level of mathematical understanding and, in turn, enhance their ability to apply mathematics in engineering courses taught during the year and in subsequent years. Through Mathematics Day, we also have the ability to generalise the level of mathematical knowledge amongst FKAB students in UKM. The first Mathematics Day was held on May 4, 2017 on the 12th week of the second semester of the 2016/2017 academic session. The activities carried out included a poster competition for final year students, an academic lecture, project exhibitions and mathematical results. All UPAK staff were involved in Mathematics Day, and all activities involved the top management of the Dean's Office at FKAB. This Mathematics Day was launched by the Dean of the Faculty of Engineering and Architecture, Prof. Dato 'Ir. Dr. Abdul Wahab Mohammad.

In Activity 1, the poster competition (Figure 1), 12 final year students presented an analysis of their final year project (FYP) by using only mathematical and statistical elements. The competition was judged by an academic panel (Prof. Dr. Azami Zaharim, Prof. Dr. Mohd Syuhaimi Abdul Rahman and Prof. Dr. Zulkifli Mohd Nopiah), an industry panel (Mr. Harley Ooi and Mr. Desmond Lim Teck Siong) and UKM alumni (Mr. Muhammad Nurhilmi Saharin and Mr. Izwan Hadi Zamhuri). Meanwhile, for the academic lecture (Activity 2, Figure 2), UPAK invited Prof. Dr. Roslinda Mohd Nazar, a lecturer from the Faculty of Science and Technology at UKM to speak about her field of study, where mathematical applications are used in research and product development. The organiser encouraged students to follow the academic lecture so they would be aware of the use of mathematical elements in their analysis and the application of mathematics in daily life.

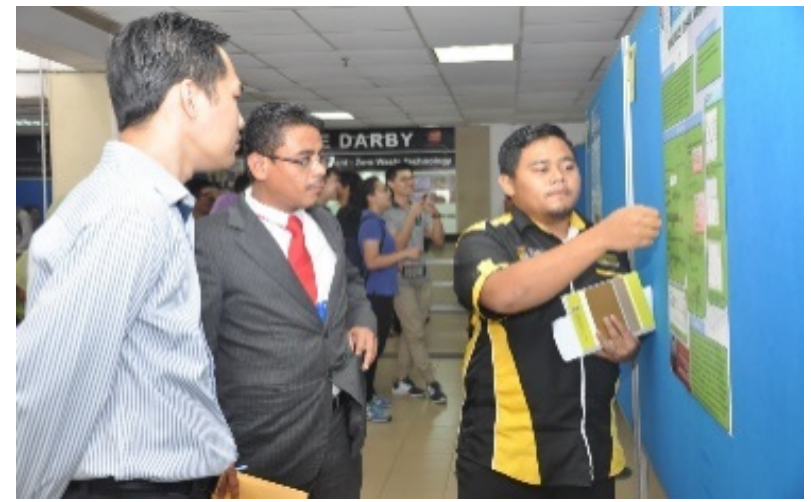

Figure 1. Activity 1 (Student poster contest)

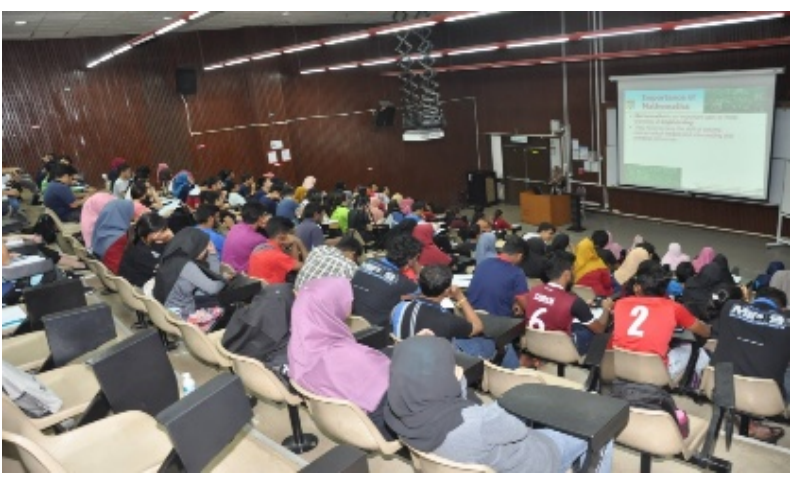

Figure 2. Activity 2 (Academic lecture)

Activity 3 (Figure 3) was the project exhibition and the presentation of the student's projects about mathematics. The exhibition and presentation were intended to demonstrate mathematical applications in everyday life. The exhibition was an all-day activity, starting from the opening ceremony until the prize presentation ceremony. The materials presented included the student projects involving the use of mathematics. Activity 4 involved mathematical games (Figure 4). Sudoku and Rubik's cube were additional activities that students could try to test their logic. Figure 5 shows Activity 5, which was the Industry Fair. The industry was also invited to create exhibitions on mathematics and its applications in the industry.

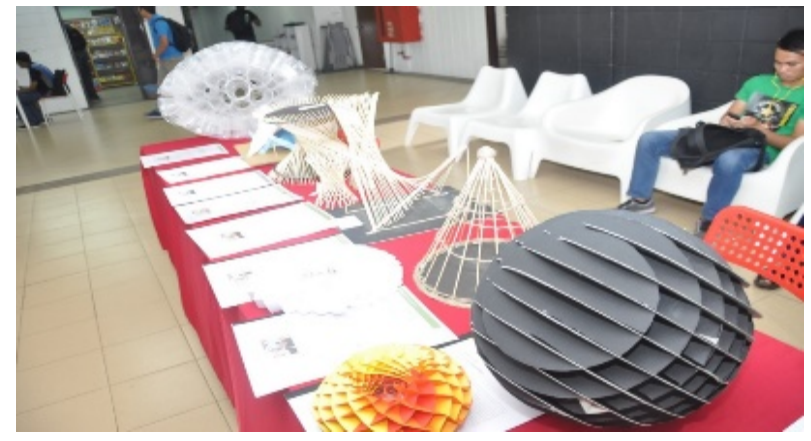

Figure 3. Activity 3 (Project exhibition and student projects)

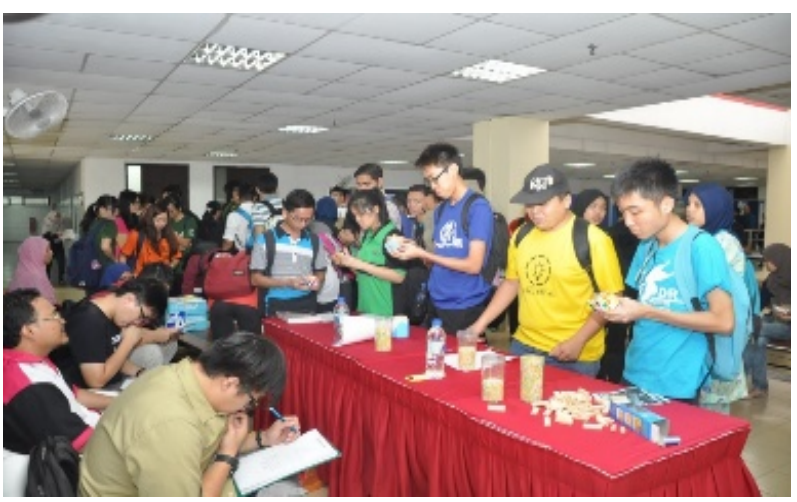

Figure 4. Mathematical games 


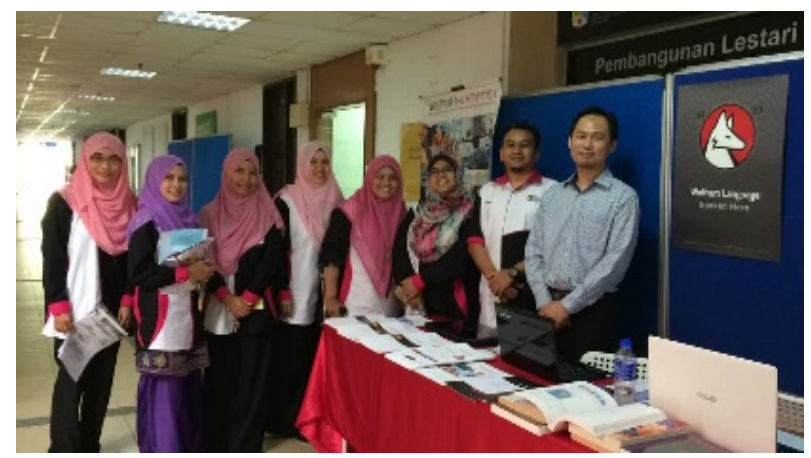

Figure 5. Exhibition from the industry

\section{Methodology}

\subsection{Data I}

Table 1. Student Poster Titles

\begin{tabular}{|c|ll|}
\hline Department & \multicolumn{1}{|c|}{ Titles of Student Posters } \\
\hline JKAS & $\bullet$ & $\begin{array}{l}\text { Marketability of recyclables } \\
\text { Salinity variations of surface water along the } \\
\text { Straits of Johor from 2003 until 2014 } \\
\text { Study of heavy metal pollution distribution } \\
\text { along Johor Strait from 2003-2014 }\end{array}$ \\
\hline JKMB & $\begin{array}{l}\text { Taguchi and ANOVA methods to analyse the } \\
\text { results of machining of alloy steel alloys } \\
\text { using finite element method, "Thirdwave }\end{array}$ \\
\hline JKKP & $\begin{array}{l}\text { AdvantEdge" } \\
\text { Global-local overlay technique for fatigue } \\
\text { crack growth analysis }\end{array}$ \\
\hline JKEES & $\begin{array}{l}\text { Water quality control of UKM flow channel } \\
\text { using blurry logic } \\
\text { Analyse the movement of the pipeline } \\
\text { inspection toll (PIG) in natural gas pipeline }\end{array}$ \\
& $\begin{array}{l}\text { Engineering lakes water quality control using } \\
\text { buffer neural networks and blurred neural } \\
\text { networks }\end{array}$ \\
\hline - $\begin{array}{l}\text { Impact light communication } \\
\text { Multiplexing Bragg grain time division } \\
\text { (TDM-FBG) with Golay coding } \\
\text { Optical sensor to assess the maturity of oil } \\
\text { palm fruit } \\
\text { Align polystyrene particles using acoustic } \\
\text { plate wave mode }\end{array}$ \\
\hline
\end{tabular}

The main focus of this paper is to study the relevance of mathematical elements and applications of topics in the Engineering Mathematics course in students' posters. The data were obtained from the FYP student posters presented in the 2016/2017 academic session of FKAB at UKM. A total of 12 final year students from FKAB participated in the competition, three entries from the
Department of Civil Engineering and Systems (JKAS), two from the Department of Mechanical and Materials Engineering (JKMB), three from the Department of Chemical and Process Engineering (DOSH) and four from the Department of Electrical, Electronic and Systems Engineering (JKEES). Information on the student poster titles from each department is listed in Table 1.

\subsection{Data II}

Reports from students who were present during the event were also analysed to determine the effectiveness of the activity. The expected outcome of the student reports was interpreted using the statistical descriptive method, and it was expected that students would give a positive reaction. A total of 30 respondents were selected to study their reaction to Mathematics Day 2017. The respondents were selected randomly from Year 1 students in JKAS for the 2016/2017 academic session.

\section{Results and Discussion}

Overall, most of the students who participated in the Mathematics Day poster competition were from JKEES while the least number of students came from JKAS. Figure 6 shows the number of students from each department participating in the poster competition. JKAS offered three poster titles related to Engineering Statistics courses, JKMB offered two poster titles related to Engineering Statistics and Linear Algebra courses, JKKP offered three poster titles related to the Differential Equation course and JKEES offered four poster titles, of which three were associated with the Complex Analysis course and one to the Vector Calculus course. The associations of the student posters with the offered Mathematics courses are shown in Table 2.

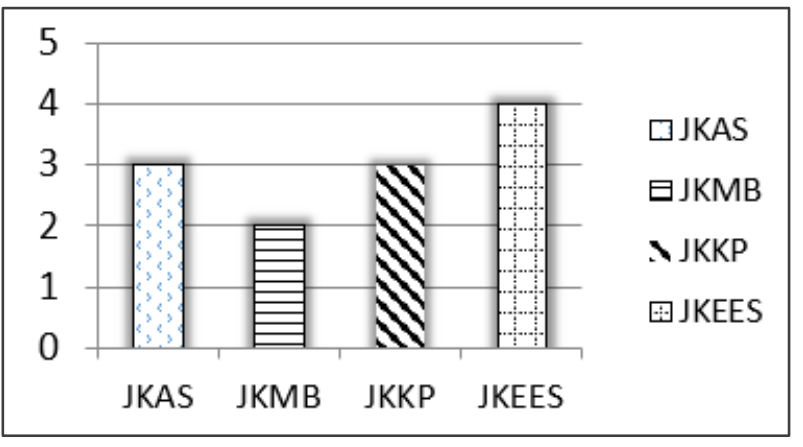

Figure 6. Number of students from each department participating in the poster competition 
Table 2. Relationship between student posters and the Mathematics courses offered

\begin{tabular}{|c|c|c|}
\hline Department & Title of Student Poster & $\begin{array}{l}\text { Relationship with an } \\
\text { Engineering } \\
\text { Mathematics subject }\end{array}$ \\
\hline JKAS & $\begin{array}{l}\text { - Marketability of recyclables } \\
\text { - Salinity variations of surface water along the Straits of Johor from } \\
2003 \text { until } 2014 \\
\text { - Study of heavy metal pollution distribution along Johor Strait from } \\
\text { 2003-2014 }\end{array}$ & $\begin{array}{l}\text { Engineering Statistics } \\
\text { Engineering Statistics } \\
\text { Engineering Statistics }\end{array}$ \\
\hline JKMB & $\begin{array}{l}\text { - Taguchi and ANOVA methods to analyse the results of machining } \\
\text { of alloy steel alloys using finite element method, "Thirdwave } \\
\text { AdvantEdge" } \\
\text { - Global-local overlay technique for fatigue crack growth analysis }\end{array}$ & $\begin{array}{l}\text { Engineering Statistics } \\
\text { Linear Algebra }\end{array}$ \\
\hline JKKP & $\begin{array}{l}\text { - Water quality control of UKM flow channel using blurry logic } \\
\text { - Analyze the movement of the pipeline inspection toll (PIG) in } \\
\text { natural gas pipeline } \\
\text { Engineering lakes water quality control using buffer neural networks } \\
\text { and blurred neural networks }\end{array}$ & $\begin{array}{l}\text { Differential Equation } \\
\text { Differential Equation } \\
\text { Differential Equation }\end{array}$ \\
\hline JKEES & $\begin{array}{l}\text { - } \quad \text { Impact light communication } \\
\text { Multiplexing Bragg grain time division (TDM-FBG) with Golay } \\
\text { coding } \\
\text { - } \quad \text { Optical sensor to assess the maturity of oil palm fruit } \\
\text { Align polystyrene particles using acoustic plate wave mode }\end{array}$ & $\begin{array}{l}\text { Vector Calculus } \\
\text { Complex Analysis } \\
\text { Complex Analysis } \\
\text { Complex Analysis }\end{array}$ \\
\hline
\end{tabular}

The students showed a very positive reaction to the Mathematics Day program, with 27\% reporting that the program 'improves knowledge on various aspects', approximately $6 \%$ stating that they are 'able to get new information' and $3 \%$ indicating that the program 'provides info that is very useful' (Figure 7). A total of three feedbacks have the same percentage at $7 \%$, including 'improves the application and knowledge of Mathematics in engineering courses', 'gets knowledge for mathematics application in the real world' and 'improves knowledge in geometric form'. Two feedback items have the same percentage of $10 \%$, namely, 'increases knowledge especially in mathematical subjects' and 'cultivates interest in Mathematics subjects.

Therefore, the results of these two sets of data show that the objectives of Mathematics Day were successfully achieved. This program helps students to master mathematical and engineering courses more accurately and effectively so that they can advance themselves in engineering courses. In addition, it helps students open their minds to increase their appreciation and level of mathematical understanding and, in turn, enhance their ability to apply mathematics in engineering courses taught during the year and in subsequent years. 


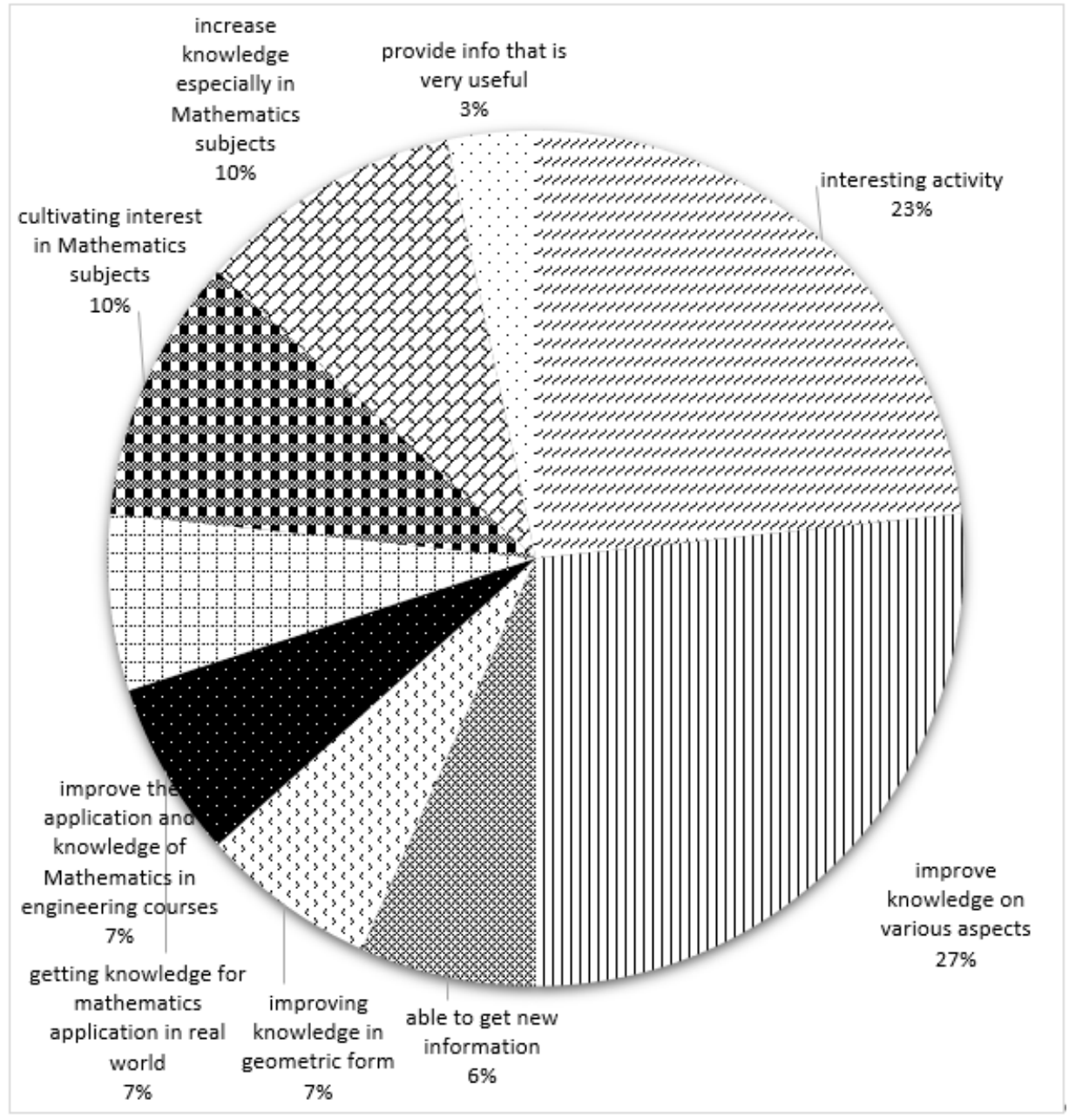

Figure 7. Student feedback on Mathematics Day program

\section{Conclusions}

With all the activities conducted throughout the Mathematics Day program, UPAK expects to overcome the inability amongst FKAB students to apply mathematics into engineering courses by showing them mathematical applications in research and everyday life. Through the program, FKAB can not only produce sustainable graduates in their area of expertise but also graduates who will be able to handle mathematical problems found in their work as engineering practitioners at their respective workplaces. Hopefully, with Mathematics Day and the activities carried out during the program, FKAB students will be brought to a higher level in the field of study they are involved in, which is consistent with the aspirations of UKM as a research university. The findings of this study show the integration of mathematical elements and applications in the posters designed by final year students at FKAB, UKM, and the relevance of the design with the mathematical courses offered. The reports of students who were present during the activity have provided a very positive reaction. In the future, this program will be implemented every year in the poster for FKAB at UKM. More effective questionnaires and statistical tests will also be implemented so that more descriptive and statistical analyses can be carried out. The effective analysis of Mathematics Clinics conducted by the UPAK every semester will be referred to for application in this program [15-17].

\section{Acknowledgement}

This study was supported by grants GGPM-2017-087 and FRGS/1/2018/TK04/UKM/02/15. The authors would like to express their gratitude for the cooperation of all parties involved in this study.

\section{REFERENCES}

[1] E. Sulaiman, Pengenalan Pedagogi. Johor: Penerbit Universiti Teknologi Malaysia, 2004. 
[2] M. Efstathios, M. M. Maria and M. Chrystalla, "Toward a more constructive use of technology in mathematics and science", in Information and Communication Technologies: From Theory to Applications, IEEE, 2004, pp. 115-116.

[3] N.A. Ismail, Z.M. Nopiah, I. Asshaari, H. Othman, N.M. Tawil and A. Zaharim, "Mathematical performance of engineering students in Universiti Kebangsaan Malaysia (UKM)”, Procedia - Social and Behavioral Sciences, vol. 60, 2012, pp. 206-211.

[4] N. Razali, H. Othman, N.A. Zainuri, F.M. Hamzah, I. Asshaari, F.H.M. Ariff and S. Darul, "Modern or traditional teaching strategy in learning engineering mathematics course”, Journal of Engineering Science and Technology, vol. 11, pp. 13-20, 2016.

[5] N. Misran, S.A. Osman, R. Hamid, N.T. Kofli, N. Saibani, N. Arsad, M.S. Mastar, Z.M. Nopiah, B. Bais, H. Husain and D.eds. Nordin, K-Novasi pengajaran \& pembelajaran UKM (Pendidikan Kejuruteraan dan Alam Bina): mentransformasi pengajaran dan memperkasa pembelajaran. Pusat Penyelidikan Pendidikan Kejuruteraan, Fakulti Kejuruteraan dan Alam Bina, Universiti Kebangsaan Malaysia, 2014.

[6] N. Idris, Pedagogi Dalam Pendidikan Matematik. Kuala Lumpur: Utusan Publications, 2001.

[7] A. Montague-Smith, "Mathematics teaching and learning: past, present and future", in Using ICT in Primary Mathematics, David Fulton Publishers, 2014, pp. 30-57.

[8] S. Freeman, S.L. Eddy, M. McDonough, M.K. Smith, N. Okoroafor, H. Jordt and M. P. Wenderoth, “Active learning increases student performance in science, engineering, and mathematics", Proceedings of the National Academy of Sciences, vol. 111, no. 23, 2014, pp. 8 410-8415.

[9] S. Han, R. Capraro and M.M. Capraro, "How science, technology, engineering, and mathematics (STEM) project-based learning (PBL) affects high, middle, and low achievers differently: The impact of student factors on achievement”, International Journal of Science and
Mathematics Education, vol. 13, no. 5, pp. 1089-1113, 2015.

[10] E. Ring-Whalen, E. Dare, G. Roehrig, P. Titu and E. Crotty, "From Conception to Curricula: The Role of Science, Technology, Engineering, and Mathematics in Integrated STEM Units”, International Journal of Education in Mathematics, Science and Technology, vol. 6, no. 1, pp. 343-362, 2018.

[11] M. Carr, M. Prendergast, C. Breen and F. Faulkner, "How well do engineering students retain core mathematical knowledge after a series of high threshold online mathematics tests?", Teaching Mathematics and its Applications: An International Journal of the IMA, vol. 36, no. 3, pp. 136-150, 2016.

[12] A. Andersson, P. Valero and T. Meaney, "I am [not always] a maths hater": Shifting students' identity narratives in context”, Educational Studies in Mathematics, vol. 90, no. 2, pp. 143-161, 2015.

[13] M. Abels, V. Jonker, R. Keijzer and M. Wijers, Let's have a look behind the code: The Big Mathematics Day 2016 (Netherlands) about coding without computer, 2016.

[14] E. Berardini, J. Cohen, G. Geoffroy and A. Iezzi, "Pi Day: An International Festival of Mathematics", EMS Newsletter, vol. 3, no. 107, pp. 36-37, 2018.

[15] A. Jedi, W.L. Ang, N. Zulkarnain, Z.M. Nopiah, F.H.M. Arif \& H. Othman, "Pemantapan pemahaman kalkulus vektor melalui klinik matematik”, Prosiding Seminar Pendidikan Kejuruteraan dan Alam Bina, 2017, pp. 42-47.

[16] Jedi A, Shamsudeen A, Razali N, Othman H, Zainuri NA, Zulkarnain N, Bakar NA, Pati KD, Thanoon TY. Statistical Modeling for Nanofluid Flow: A Stretching Sheet with Thermophysical Property Data. Colloids and Interfaces. 2020 Mar;4(1):3.

[17] Razali N, Jedi A, Zainuri NA. The implementation of extrapolation with smoothing technique in solving stiff ordinary differential equations. International Journal of Structural Integrity. 2020 Mar 25. 